\title{
Notes on Recent Experiments relating to the Growth and Rearing of Food-fish at the Laboratory.
}

Reference has been already made in the Report of the Council to the successful (artificial) fertilization and hatching of the eggs of the sole, and to the study of the plaice eggs which were naturally fertilized and hatched in the aquarium. With regard to the rearing of lobsters, Mr. Weldon and Mr. Fowler have contributed the following notes on their experiments :

\section{The Rearing of Lobster Larve.}

In the intervals of other and more pressing work we have made during the months of June and July a few experiments on the rearing of lobster larvæ; and although for various reasons these experiments were not successful, a few notes on the methods pursued and the conclusions deduced may prove of use to others engaged in the same task. It is possible that the cause of failure was merely that the eggs had suffered in being brought in, from the struggles of the mother lobsters; certainly a very large number of larvæ died in the act of hatching, too weak to extricate themselves from the shell. The shortness of the hatching season, however, prevented the undertaking of new and special arrangements for carrying them. Other possible causes of failure were want of space and the difficulty of providing a suitable food. As to the question of space, most pelagic organisms cannot bear to be confined within narrow limits, whether vertical or horizontal ; they must, if they are to thrive, have a large superficial range, as well as a considerable depth of water to which they may sink when such physical conditions as light and heat demand it. As the Association had unfortunately no funds to place at our disposal for this special purpose, the largest body of water available was a tank of sixty-three feet superficial area, and containing about 600 gallons ; the water was in constant circulation, and formed part of the 
general system of the aquarium. Rock-work was arranged for the mother lobsters, and the inflow and outflow were guarded by "smut-wire" screens; the surface was constantly broken by a current through a fine "rose." In this tank the larvæ flourished better than elsewhere, but we were unable to keep them alive for more than twelve days after hatching. Part of the tank was boarded over for shade, but the larvæ appeared to avoid this dark part, and to select shady corners in the well-lit area. So long as they were strong they remained at the surface, and only sank to the bottom when beginning to turn red (the recognised symptom of weakness). They exhibited no liking for the rock-work.

The problem of a suitable food was not entirely solved in spite of many experiments. The yolk of a hard-boiled egg, crushed crab (Carcinus menas, Portunus depurator), boiled liver, the contents of the tow-net (at that period chiefly Noctiluca and Copepoda), and live shrimp larvæ, were all partially, none absolutely, successful. The first three are seen and eaten with avidity when floating as small particles about one to six inches below the surface; when at the surface or on the bottom they are apparently not touched, and it was not advisable to keep pouring finely divided food constantly into the tank owing to the danger of fouling the water; shrimps placed in the tank to eat the sunken food ate the larvæ by preference : shore-crabs were found to answer better as scavengers, but cannot take up fine particles. Finding that food is only taken when at this position in the water, we caused small brackets to be suspended about four inches below the surface, on which the food (crushed crab) was placed in common red flower-pot saucers; the larvæ swarmed into the saucers, and perished miserably. This occurred partly because they were attracted by the bright colour and unable to leave it, partly because the sides of the saucer were so steep that they found difficulty in getting out. An ordinary white saucer, however, with less steep sides produced nearly the same mortality. That the brightness of the saucer was largely the cause of death was demonstrated by placing an empty saucer on the bracket, into which they crowded and died. The brackets were then blackened by charring, and the food placed directly upon them ; it was not touched. Large pieces of food suspended from wooden spits were seldom touched. It was definitely concluded from these experiments that whatever food is used must be floating in the condition of small particles at a short distance below the surface, i.e. in the same position as the natural pelagic food of the larvæ at sea, whether this consist of Copepoda, other Decapod larvæ, trochospheres, fish ova, or other members of the pelagic fauna. As to the other two forms of food tried, the Noctilucæ were 
apparently eaten, the shrimp larvæ (Mysis stage) certainly were attacked; and from the fact that the young lobsters attack and devour each other it is probable that Decapod larvæ form at any rate part of their usual food. The contents of a tow-net taken near the Eddystone on August 6th, which held a young lobster, consisted chiefly of Megalops and Mysis stages of Decapoda.*

The qualification for success in all experiments of this kind is the reproduction, on a small scale and under the control of the experimenter, of the essential factors in the environment of the animal to be reared. The conditions which seem to us most likely to yield success, both in hatching fish and lobsters, are the following :- The establishment of a large and deep pond (say 1000 square feet in area, and $2-3$ fathoms deep at some places) on a rocky coast, the levels being so arranged that it should stand always about four fifths full, while the remaining fifth should fill through filters on the top of ordinary and spring floods, emptying slowly on the ebbs. A flora should be allowed to form in the pond for a year or so before it is required for hatching purposes; and all predatory animals should of course be kept down. At a higher level than this pond should be two or three lesser ponds, kept well stocked with breeding animals whose larvæ are likely to serve as food (crabs and shrimps), communication with the lobster pond being maintained by guarded siphons which would carry over the larvæ, but not the adults. While these would supply one element of food, the daily tide would bring an additional quantity of pelagic organisms, which could be supplemented by the tow-net, and, if necessary, by artificial food (crushed crab, \&c.). The ova and embryos of common fish would probably prove a most appropriate pabulum, cheaply and easily obtainable by artificial fertilization; but we had no opportunity of experimenting with them during this hatching season.

The mere hatching of the eggs of the lobster, whether they are left on the mother, or are stripped from her and hatched in appropriate apparatus, presents, of course, no difficulties; it is easy to turn myriads of young lobsters loose in the sea with a very small expenditure; but the general belief that over-fished grounds can be replenished in this way is still open to very serious criticism. There is as yet no proof that this procedure has produced or can produce any effect whatever in restocking depopulated areas. We do not desire to discuss this question here. Our experiments were a preliminary attempt to ascertain in what manner young lobsters might best be reared in large numbers to the age at which they assume the characters and habits of the adult; to achieve this is simply

* Young stages of the lobster have been rarely taken in the surface tow-net by the Association both by day and by night, but never elsewhere than at the surface. 
a matter of experience, $i$. e. of continued experiment. It has already once (1885) been done by Captain Dannevig in Norway; and if any benefit come to the lobster fishery by turning the newly hatched larvæ loose in their most helpless phase, greater success will certainly attend the planting of over-fished grounds with young lobsters at the age at which they sink to the bottom and assume the habits of concealment of the adult.

\section{The Rearing of Larval Fish.}

By J. T. Cunningham, M.A., F.R.S.E.

The Flounder (Pleuronectes flesus, Linn.).-On May 3rd of the current year I received from Mr. Dunn, of Mevagissey, about 200 young flounders (Pleuronectes flesus), collected in the shallow pools left in Mevagissey Harbour at low tide; and on May 7 th Mr. Dunn sent another large consignment of the same kind of fish. I put the greater number of them into two shallow table-tanks, one of these tanks being in the aquarium and exposed to a good deal of light, the other in the Laboratory and somewhat dark.

These young flounders were at the stages of development represented in fig. 5, Pl. XVII, and fig. 1, Pl. XVIII of my Treatise on the Sole, the great majority at the younger of these two stages. They were very transparent with the exception of the eyes, which were fully pigmented and had a brilliantly metallic appearance. The metamorphosis in these was begun, but by no means completed; the left eye was approaching the edge of the head, and nearly all the pigment-cells had disappeared from the left side of the body. They rested for the most part on the bottom, but frequently swam about in the water in a slanting position. One of these was measured,

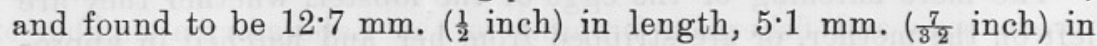
breadth.

Some of them were slightly more advanced; these were much more opaque, with more pigment on the upper side, and with the eye of the lower side on the very edge of the head. One of them measured $11.5 \mathrm{~mm}$. in length and $5 \mathrm{~mm}$. in breadth.

The tanks in which these young flounders were placed were arranged thus: the bottom was covered with fine sand, except where at one end there was gravel, separated from the sand by a wooden plank, and filling up a space below the slate partition which separated this tank from the next. Water, flowing into the tank in a couple of small jets, passed through the layer of gravel, so that the level in the tank containing the flounders was always the 
same as in the next tank, which contained an overflow pipe. In this way a constant flow of water was maintained in the tank without causing any strong current at the outflow, so that the small fish could neither escape nor be injured by a strong current of water towards the outflow.

I fed these young fish at first with minute Crustacea, procured by sifting a quantity of weeds from the shore in water. In this way numbers of small Copepods, Amphipods, and Isopods were separated from the weeds, and were then put into the flounder-tank. The little fish took this food eagerly, but the labour of preparing it was considerable. I therefore soon gave up this method, and fed the fish with chopped worms (Nereis, Nephthys, \&c.). The minced worms were strained through a vulcanite sieve, and only the smaller particles were given to the young fish. As the fish grew older other kinds of food, such as chopped Pecten and pilchard, were occasionally given, but the fish always took worm with most eagerness. During my absence from the Laboratory between July 1st and August 13th the fish were regularly fed by the attendant, and on my return I found that they were all in a healthy condition, and that they had grown very considerably, although the size of different individuals varied very much. On August 19th, of two specimens from the tank in the aquarium one measured $6.7 \mathrm{~cm}$. (25 inches) in length, the other $8 \mathrm{~cm}$. ( $\left(3 \frac{3}{16}\right.$ inches). These specimens were not the largest in the tank, but I believe that they were above the average size of the whole number. As the fish are very active, and always more or less concealed by the sand, it is, of course, impossible to ascertain the minimum and maximum size, or the average size, without killing the whole number. But it is clear that in three and a half months many of these fish have grown from about $\frac{1}{2}$ inch in length to 3 inches.

The Brill (Rhombus lævis, Gottsche).-On May 21st of the current year boys and fishermen brought to the Laboratory a number of the young of this species. They were found swimming near the surface of the water in Sutton Pool, and were taken out either by hand or with a tin pot. There had been a south wind on that and the previous days, and the fish were found at flood tide. I put twenty of these into the tank in the aquarium, where the young flounders were.

On June 11th I received fourteen more of the same species in about the same stage. Those placed with the flounders were observed to catch and devour them, so that I had another tank prepared after the same fashion, and placed all the brill in this by themselves. I could only find seventeen in the flounder-tank, so that the total number of brill isolated in the tank devoted to them 
was thirty-one. After the brill were separated from the flounders they were fed with chopped worm, which they ate very sparingly. I was unable to get any other living fish which they seemed to appreciate; to small shore-fish such as gobies they paid no attention. I was afraid that they would not eat enough of the worm to nourish themselves, but on my return to Plymouth after my holiday I found that they were alive and had grown a great deal. They still continue to live on worms, occasionally varied by Pecten and pilchard, but they never feed eagerly and voraciously as the flounders do. It is possible that in the natural condition young brill prey upon smaller fishes, and that then they grow faster than my specimens have on the diet supplied to them. But I could not afford to feed them on living young flounders, and I shall have to find some future opportunity of comparing the growth of the captive specimens with that of free individuals.

These young brill when brought to the Laboratory were 2.2 to $2.56 \mathrm{~cm}$. ( $\frac{7}{8}$ inch to $\left.1 \mathrm{inch}\right)$ in total length. They all possessed a large air-bladder, and were able to sustain themselves for an indefinite time at the surface or in mid-water; but they frequently rested on the sand at the bottom of the tank, and after a few days they swam less and less above the bottom. Their metamorphosis was nearly complete, but the eye of the lower side (the right) was either on the edge of the head or only slightly within the edge on the upper side. The dorsal fin did not extend forwards in front of the right eye as it does in the adult, but only overlapped that eye for about one third of its longitudinal diameter. The anterior dorsal fin-rays were simple and undivided externally. Scales in the skin were not visible externally.

On August 23rd I took out one of these brill and preserved it in

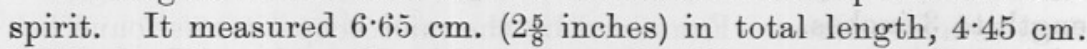
( $1 \frac{3}{4}$ inches) in greatest breadth. It was in all respects closely similar to the full-grown adult. The first five of the dorsal fin-rays were divided into two branches at the ends ; and, in the first two, indications of further subdivision were visible. The dorsal fin extended forwards in front of the transverse level of the right eye. The circular scales were distinctly visible all over the upper (left) side by the aid of a simple lens.

Thus these brill have grown from about 1 inch to over $2 \frac{1}{2}$ inches in length in two and a half months.

Five-bearded Rockling (Motella mustela, Linn.).--Several specimens of the young of this species were brought to the Laboratory on May 21st, having been caught in Sutton Pool along with the young brill. When brought in they were about an inch long. One species of Motella was spawning in our tanks in April of the present year, 
and the present species probably spawns about the same time, so that the young specimens obtained from Sutton Pool were probably three or four weeks old. They were placed with the young flounders, and throve well, feeding on the chopped worm supplied to the latter. One killed on August 19 th was $3 \frac{1}{8}$ inches long $(7 \cdot 9 \mathrm{~cm}$.).

Grey Mullet (Mugil chelo, Cuvier).-Last year a number of the young of this species were brought to the aquarium by $\mathrm{Mr}$. W. Bateson, and are mentioned in his paper in the previous number of this Journal. These little fish were taken in the open sea, but there can be no doubt that they were hatched the same year, though in which month it is not easy to decide. When obtained by Mr. Bateson in July and August they were about $\frac{3}{4}$ of an inch long. I obtained some of the same species this year in Cawsand Bay on May 14th, which were $11 \mathrm{~mm}$. ( $\frac{7}{16}$ inch) in length. These were, in all probability, from their almost larval appearance, not more than one month old, so that probably the species spawns in April.

Some of Mr. Bateson's specimens have been living in the aquarium tanks up to the present time (August, 1890). One of these

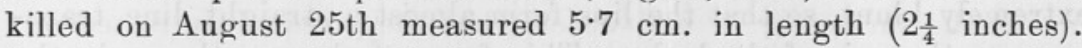
Another specimen, brought in from the sea this year, is somewhat larger, but not more than 3 inches long; this specimen is doubtless also in its second year, and has probably grown a little more in its free condition than the captive specimens.

Both these young mullet and the adults in the tanks are fond of a kind of food which no other fish has ever attempted to eat, namely, the dirty-looking, fleecy vegetable growth which covers the sides of the tanks and the rock-work.* I hare watched both the young and old individuals browsing almost like cattle on this growth. The stuff is of a dark brown, almost black, colour, and has a ragged offensive appearance. Examined by the microscope it was found to consist chiefly of Diatomaceæ. It was composed of interlacing filaments, formed by the filamentous species of Diatoms, covered by sessile or separate forms; among the Diatom filaments were also some others belonging to another class of Algæ, the Cyanophyceæ; these resembled the genus Tolypothria, and were of a bluish-green colour. (The plants were examined by Professor T. Johnson, who is at present studying at the Laboratory.) This vegetable growth was found in abundance in the stomach and intestines of the young mullet killed on August 25th. It is somewhat surprising to find a fish, which belongs to the highest class of animals, living directly on Diatoms, which are among the most lowly organised of plants.

The mullet in our tanks will eat sparingly of other kinds of food,

* This growth occurs also in other aquaria; for instance, at Amsterdam and at the Crystal Palace.-ED. 
provided it be soft. Mr. Bateson fed his young specimens on minced worm ; the adults will also eat worms, chopped Pectens, roe or milt of herring and pilchard. In fact, they nibble at almost any kind of soft food, but never swallow large pieces greedily, as many species of fish do.

Our mullet are also occasionally seen to take up a little of the gravel at the bottom of the tank, and eject it again from the mouth.

It is well known that grey mullet are usually found in the neigh. bourhood of docks, piles, piers, harbours, \&c., and that they ascend estuaries. It is probable that they always live close to the shore, and never go into deep water far from land. Considering this natural habit and the mode of feeding observed in our tanks, it may reasonably be inferred that this species feeds largely on Diatoms and other lowly organised Algæ, which always form a coating over the surface of submerged masonry, wood, or iron, and over rocks. It is interesting to note that the structure of the fish is peculiarly adapted for such a mode of feeding. In the first place, the jaws, instead of projecting to a point as they do in predatory fishes, are extremely blunt, so that the lips form almost a straight line transverse to the axis of the body. This form of the mouth, as in the muzzle of herbivorous ruminants, is especially adapted for browsing on vegetable growths covering a flat, hard surface. Secoudly, there are no teeth in the jaws; the edge of the lower jaw is sharp and straight, while the upper lip forms a thick elastic pad against which the lower jaw can bite. This arrangement reminds one of the jaws of a ruminating animal, such as a sheep or an ox, in which the cutting edge formed by the incisors of the lower jaw bites against the hard toothless pad formed by the gum of the upper jaw.

But these and other peculiarities in the structure of the grey mullet are not exclusively adapted to feeding off hard surfaces. Dr. Günther states that the fishes of this genus feed on organic substances which are mixed up with the sand or mud. Day mentions that they are observed in an aquarium to suck in the sand, the coarser portion of which they again eject. They are frequently seen to do this in our tanks, but they never feed industriously in this way as they do off the surface of the rocks and sides of the tanks. Day also mentions that various minute molluscs, both bivalves and Gasteropods, small Crustacea, and fragments of Zostera and Confervæ, have been found in mullets' stomachs.

It is evident, therefore, that, unlike most marine fishes, the grey mullet lives largely, though not exclusively, on plants, and particularly on the lowest forms of Algæ, especially the Diatomaceæ. The internal organs of these fishes, which differ so much from those of the majority of fishes, and resemble in many respects those of grami- 
nivorous birds, are especially adapted to this peculiar kind of food. Teeth are entirely absent, those of the pharyngeal bones being replaced by horny papillæ above and horny ridges below. The gill rakers have the form of lamellæ running transversely to the gill arches, and the whole pharynx thus forms a filtering apparatus, minute nutritious organisms being prevented from passing through the gill apertures and swallowed, while coarse hard substances are ejected from the mouth. The pyloric portion of the stomach forms a globular gizzard, lined with a tough epithelium and surrounded by a thick and strong muscular layer, and thus similar to the gizzard of the majority of birds. The intestines are also extremely long and convoluted, as, for example, in a common fowl; and there is also some resemblance to the entrails of the latter in the soft texture and yellowish-green colour.

The fact that grey mullets feed on Diatoms probably explains the following. On May 9th Mr. Dunn sent me a young specimen $\frac{7}{8}$ of an inch long, on which there was a tuft of brownish-yellow threads projecting from the side of the head. At first sight it seemed as though an abnormal growth of the gills had taken place. But on examination I found that the tuft was attached by a kind of stem to the ventral edge of the right operculum, and had nothing to do with the gills. Under the microscope the growth was seen to consist of branched transparent gelatinous tubes filled with frustules or cells of a Diatom; the Diatom itself forms the branching tubes. It is a Schizonema; the species is probably S. Dilwynii. It is likely that a frustule of this Diatom had at some time or other passed by accident from the pharynx of the fish through the gill clefts, and had then adhered to the operculum and commenced to grow.

Breeding of the Poor Cod and Pouting.-Several specimens of each of these two species, Gadus minutus and Gadus luscus, have been living together in a tank of the aquarium since the summer of 1889 . In March of the present year most of them were seen to be swollen with ova, and floating eggs were found in the tank. I was too much engaged to collect a number of the eggs and hatch them, but in order to determine the character of the eggs I squeezed a female of each species on April 8th, and examined the ripe ova which were thus expelled. The eggs of both species resembled those of the cod, whiting, and haddock in all respects except size; that is to say, the yolk was perfectly homogeneous and without oil-globules, and the perivitelline space, or space between the egg and its envelope, very small. The diameter of the egg of $G$. minutus, including the envelope or shell, was $1.02 \mathrm{~mm}$; that of G. luscus very slightly larger, namely, 1.05 to $1.15 \mathrm{~mm}$. 